\section{MEDICO RESEARCH CHRONICLES \\ ISSN NO. 2394-3971 \\ DOI No. 10.26838/MEDRECH.2021.8.6.565}

Contents available at www.medrech.com
OPEN ACCESS

\title{
MAGNESIUM SULFATE VERSUS FENTANYL AS AN ADJUVANT WITH BUPIVACAINE IN SUPRACLAVICULAR BRACHIAL PLEXUS BLOCK- A COMPARATIVE STUDY
}

Dr. MD. Emdad Hossain ${ }^{1}$, Dr. Panna Lal Saha ${ }^{2}$, Dr. Saiful Mahmud Tusher ${ }^{3}$, Dr. Md. Nazmus Sakeb Chowdhury ${ }^{4}$, Dr. Sushmita Biswas ${ }^{5}$, Dr. Sultana Nasrin ${ }^{6}$, Dr. Halima Khanam ${ }^{7}$, Dr. Sazia Afrin ${ }^{8}$

1. MBBS, DA. Junior Consultant, Anaesthesiology, Mithamain Upazila Health Complex, Kishoregonj, Bangladesh

2. MBBS, DA, Junior Consultant, Anaesthesiology, Magura 250 Bed Sadar Hospital, Magura, Bangladesh

3. MBBS, DA, FCPS, Anesthesiologist, Department of Anaesthesia, Pain, Palliative and Intensive Care, Dhaka Medical College Hospital, Dhaka, Bangladesh

4. MBBS, DA, FCPS, Anesthesiologist, Department of Anaesthesia, Pain, Palliative and Intensive Care, Dhaka Medical College Hospital, Dhaka, Bangladesh

5. MBBS, Medical Officer, Sher E Bangla Medical Collage Hospital, Barishal, Bangladesh

6. MBBS, M. Phil, Pharmacology, Lecturer, Netrokona Medical College, Netrokona, Bangladesh

7. Medical Officer, Department of Obstetrics and Gynecology, Dhaka Medical College Hospital, Dhaka, Bangladesh

8. MBBS, Resident-Skin \& VD, Phase B, Dhaka Medical College Hospital, Dhaka, Bangladesh

\section{ARTICLE INFO}

Article History

Received: October 2021

Accepted: November 2021

Key words: Block, Group, Brochial Plexus block, Bupivacaine, Study, Magnesium

\section{AbSTRACT}

Background: Brachial plexus block is an excellent method for attaining optimal operating conditions for upper limb surgeries. This method produces complete muscular relaxation, maintaining haemodynamic stability. Objectives: The objective of the study was to evaluate the effectiveness of magnesium sulfate and fentanyl as an adjuvant to bupivacaine in supraclavicular brachial plexus block. Methods: This observational study was conducted in the Department of Anaesthesiology and ICU, Bangladesh Medical College Hospital over a period of six months after acceptance of protocol. Study populations were patients of ASA Status I-II planned for upper limb orthopedic surgical procedures under supraclavicular brachial plexus block. Study populations were randomly allocated into one of the two groups, 30 in each- group A \& B. Group A - Patients received $38 \mathrm{ml}$ of $0.25 \%$ bupivacaine with $100 \mu \mathrm{g}(2 \mathrm{ml})$ of fentanyl to make a total volume of 40 $\mathrm{ml}$. Group B - Patients given $38 \mathrm{ml}$ of $0.25 \%$ bupivacaine with $80 \mathrm{mg}$ $(2 \mathrm{ml}, 4 \%)$ magnesium sulfate. Parameters observed were demographic, hemodynamics, onset, and duration of sensory and motor block, 
Corresponding author Dr. MD. Emdad Hossain*

analgesia. By using SPSS, version 22.0 data were analyzed. A Chisquare test was applied for qualitative data and an Unpaired t-test was applied for quantitative data. the p-value of $<0.05$ was considered as statistically significant. Results: In this study, there was no significant difference between groups in respect of demographic (age, gender) and ASA status $(p>0.05)$. Regarding hemodynamics (heart rate, systolic blood pressure, diastolic blood pressure, mean arterial pressure) were no statistically significant differences between Group A and Group B $(p>0.05)$. The onset of sensory $(p=0.825)$ and motor block $(p=0.968)$ was not statistically significant between the two groups. Duration of sensory and motor block was significantly increased in Group A compared to Group B $(\mathrm{p}=0.001)$. Duration of analgesia was no significant difference between the two groups $(\mathrm{p}=0.127)$. No significant difference in the total number of rescue analgesics between Group A and Group B $(p=0.640)$. From this study, it is found that magnesium sulphate, as well as fentanyl as an adjuvant to bupivacaine, prolongs the duration of sensory and motor block in supraclavicular brachial plexus block. Conclusion: Magnesium sulphate, as well as fentanyl as an adjuvant to bupivacaine, prolongs supraclavicular brachial plexus block.

2021, www.medrech.com

\section{INTRODUCTION}

For perioperative pain management, peripheral nerve blocks are gaining widespread popularity because of their specific advantages over general anesthesia and central neuraxial anesthesia. One should be familiar with the clinical pharmacology of the local anesthetic drugs and adjuvants, to select an appropriate local anesthetic drug for a specific clinical situation. By inhibiting the excitatory process in the nerve endings or in the nerve fibers, local anesthesia exerts its effect. The sequence of events is generally accepted as the mechanism of action of local anesthetic agents are binding of the local anesthetic moiety to the receptor sites in the nerve membrane, reduction in sodium permeability, decrease in the rate of depolarization, failure to achieve threshold potential, lack of development of propagated action potential and conduction blockade. Brachial plexus blockade now-a-day is the cornerstone of the peripheral nerve regional anesthesia practice of most anesthesiologists. ${ }^{1}$ Brachial plexus block is controlled by various approaches viz. supraclavicular, interscalenous, infraclavicular and axillary routes. ${ }^{2}$ The supraclavicularr level is an ideal site to achieve anesthesia of the entire upper extremity just distal to the shoulder as the plexus remains relatively tightly packed at this level, resulting in a rapid and high-quality block. The supraclavicular block is often called the "spinal of the arm for this reason." 3 With local anesthetics for perioperative analgesia leads to stable hemodynamics intraoperatively, smoother emergence from general anesthesia, sensory blockade of the brachial plexus. And it decreased the need for supplemental analgesics or suppositories in the Postoperative period., A brachial plexus block at the level of the clavicle can anesthetize all four distal upper extremity nerve territories without a requirement for a separate block of the musculocutaneous nerve compared to the axillary approach.4 The first brachial plexus block was performed in 1885 with cocaine by Halstead. In 1911, Hirschell described the first percutaneous technique for performing the block. $^{5}$ To local anesthetic solutions in an 
attempt to increase its efficacy and duration in recent years, it has gained popularity with the addition of various adjuncts. Systemic adverse effects and prolonged motor block are avoided along with a reduction in the total dose of local anesthetic used. With a local anesthetic solution, adjuncts like epinephrine, bicarbonate, opioids, clonidine, neostigmine, and tramadol have been injected concomitantly. Time of onset of anesthesia, duration, and quality of regional blocks, etc. are prime factors for good anesthesia. Each drug has advantages and disadvantages, so efforts were made to combine the adjuvant with local anesthetics to improve patient and surgeon satisfaction. To motor neural block, bupivacaine is frequently used as the local anesthetic for brachial plexus anesthesia because it offers the advantage of providing a long duration of action and a favorable ratio of sensory. In order to provide a better quality of anesthesia intraoperatively and prolong the duration of postoperative analgesia, various adjuvants are added to local anesthetic solutions. ${ }^{1}$ Many adjuvant drugs including Dexmedetomidine, clonidine, morphine, verapamil, midazolam, tramadol, fentanyl, alfentanil, sufentanil, and Dexamethasone have been co-administered with bupivacaine to achieve quicker onset, improve the analgesic intensity and prolong the duration of action. Magnesium sulphate and fentanyl are two such adjuvant drugs that can be used in combination with bupivacaine to enhance the analgesic efficacy of the drugs and that facilitate early achievement and prolongation of the block. ${ }^{5}$ Fentanyl being highly lipid-soluble diffuses into the spinal cord and binds to dorsal horn receptors rapidly. This produces rapid onset of analgesia with minimal cephalic spread. A previous study reported Fentanyl added to bupivacaine most efficacious regimen for brachial plexus block among patients undergoing upper limb orthopedic surgeries. ${ }^{6}$ Magnesium is the fourth most common cation in the body, has postsynaptic N-methyl D- aspartate calcium channel blocker properties. It has been used successfully to potentiate opioid analgesia to treat neuropathic pain in animals. A previous clinical study demonstrated that adding magnesium sulfate to supraclavicular brachial plexus block may increase the sensory and motor block duration and time to first analgesic use, and decrease total analgesic needs, with no side effects. ${ }^{7}$

\section{OBJECTIVE}

\section{General Objective:}

- To evaluate the effectiveness of Magnesium Sulfate and fentanyl as an adjuvant with bupivacaine in supraclavicular brachial plexus block.

\section{Specific Objectives:}

- To assess and compare the onset and duration of sensory and motor block in between Group A (receiving Fentanyl and Bupivacaine) and Group B (receiving Magnesium sulfate and Bupivacaine).

- To assess and compare the duration of analgesia by VAS score in between Group A and Group B.

- To compare, hemodynamics (HR, SBP, DBP, MAP) in between Group A and Group B.

\section{METHODOLOGY AND MATERIALS}

This was a prospective observational study. The study was conducted in the Department of Anaesthesiology and ICU, Bangladesh Medical College Hospital, Dhaka from 17th January 2020 to 16th July 2020. Ethical approval was taken from the Ethical Review Board, Bangladesh Medical College Hospital. A total of 60 patients, ASA physical status I, II who have undergone upper limb orthopedics procedures under supraclavicular brachial plexus block were included in the study. Informed consent was obtained from all the patients enrolled in the study and asked to remain too fast $6 \mathrm{hr}$. before surgery selected after their admission in Bangladesh Medical College Hospital after fulfilling inclusion and exclusion criteria. A total of 60 participants 
both male and female were recruited in this study as the study population. Patients with severe comorbidities, obesity (body mass index >35). Infections at the site of the block were excluded from the study. Depending upon the study drug administered, the patients were randomly divided into 2 groups. In Group-A, patients were given bupivacaine $(0.25 \%) 38 \mathrm{ml}$ and fentanyl $100 \mu \mathrm{g}(2 \mathrm{ml})$, total of $40 \mathrm{ml}$. In Group-B, patients were given bupivacaine $(0.25 \%) 38 \mathrm{ml}$ and Magnesium Sulfate $80 \mathrm{mg}(2 \mathrm{ml}, 4 \%)$. On the day of surgery, all patients were taken to the operation theater. Intravenous line secured with the 18-gauge cannula. The patient was positioned supine with the head turned about $30^{\circ}$ to the contralateral side. The interscalene groove palpated at its most inferior point and the latter can be felt in a plane just medial to the midpoint of the clavicle which is just posterior to the subclavian artery pulse. After a skin wheal with a local anesthetic at a very flat angle against the skin, a 22-gauge, 1.5-inch needle was directed just above and posterior to the subclavian pulse and directed caudally. The needle was advanced until paresthesia encountered or muscle contraction of the forearm is noted. If contraction was still observed, then a local anesthetic was injected. The needle insertion path was reevaluated, if the rib was encountered without paresthesia or if blood was encountered, the needle withdrawn, and the landmarks as well as the plane. The hemodynamic parameters were evaluated before administration of sample drug and after administration every $5 \mathrm{~min}$ for $20 \mathrm{~min}$ and thereafter every $30 \mathrm{~min}$ for 180 min. The onset of sensory and motor block was assessed at $5 \mathrm{~min}$ intervals up to $30 \mathrm{~min}$. The blockage was considered a failure when sensory anesthesia was not achieved within 30 min. General anesthesia is then given subsequently to these patients and excluded from the study. The duration of sensory blockade, defined as the time between the onset of sensory block and return of dull pain but $\mathrm{VAS}<3$. The duration of the motor block was assessed every 10 minutes till the ability of the patient to first move the fingers. Analgesia was assessed using a 10-point visual analog scale, in which a score of " 0 " shall indicate "no pain" and a score of "10" "worst pain imaginable." Analgesia using VAS score, at regular interval of $15 \mathrm{~min}$ for first one hour, 30 minutes for the second hour, once every 2 hours until the 8 hours and once every 4 hours for the next 12 hours in all two groups. Rescue analgesia in the form of injection pethidine $(1.5 \mathrm{mg} / \mathrm{kg})$ intramuscularly was given when VAS $>3$ in all two groups. Parametric data were reported as mean $\pm \mathrm{SD}$. A Chi-square test was applied for qualitative data and an Unpaired t-test was applied for quantitative data. a p-value of $<0.05$ was considered as statistically significant Data processing work consist of registration schedules, editing computerization, preparation of dummy table, analyzing and matching of data by SPSS version 22.0.

\section{RESULT}

Table- 1: Distribution of the patients according to age $(\mathrm{N}=60)$

\begin{tabular}{|l|c|c|c|c|}
\hline \multirow{2}{*}{ Age (years) } & \multicolumn{3}{|c|}{ Number of patients } & \multirow{2}{*}{ p-Value } \\
\cline { 2 - 4 } & $\begin{array}{c}\text { Group A } \\
(\mathrm{n}=30)\end{array}$ & $\begin{array}{c}\text { Group B } \\
(\mathrm{n}=30)\end{array}$ & $\begin{array}{c}\text { Total \& Percentage } \\
(\mathrm{N}=60)\end{array}$ & \\
\hline $18-39$ & $21(70.0)$ & $18(60.0)$ & $39(65.0)$ & \\
\hline $40-60$ & $9(30.0)$ & $12(40.0)$ & $21(35.0)$ & \\
\hline Mean \pm SD & $34.7 \pm 8.53$ & $35.21 \pm 9.42$ & & $0 . .826^{\mathrm{ns}}$ \\
\hline
\end{tabular}

Table 1 showed age distribution of history of all the 60 selected cases were taken, patients. According to the questionnaire, while studying the distribution of cases by age 
it was found that majority of the patients i.e. $65.0 \% \quad(n=39)$ were between $18-39$ years, $35.0 \% \quad(n=21)$ were between $40-60$ years.
Mean age was found to $34.7 \pm 8.53$ years. No significant differences were found between groups with respect to age.

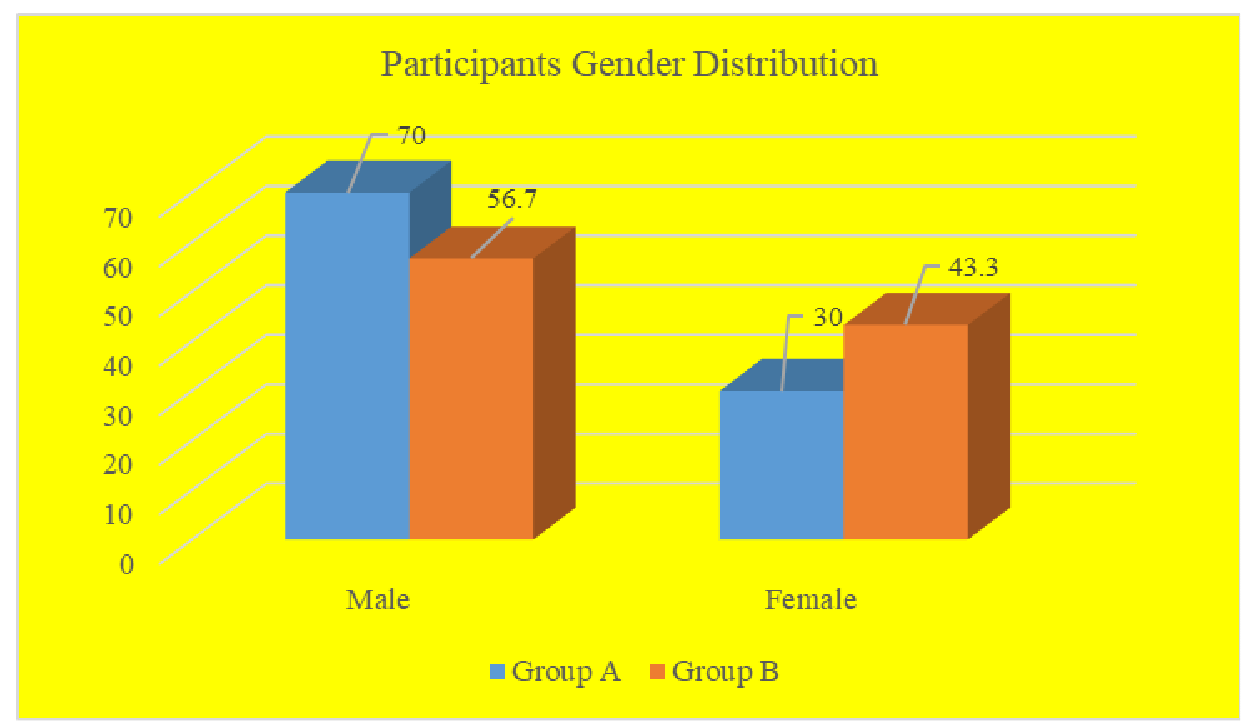

Figure I: Gender Distribution of the Participants (N=60)

Table-2: Distribution of patients according to American Society of Anesthesiologist (ASA) (N=60)

\begin{tabular}{|l|c|c|c|}
\hline \multirow{2}{*}{ Status } & \multicolumn{2}{|c|}{ Number of Patient } & \multirow{2}{*}{-Value } \\
\cline { 2 - 3 } & $\begin{array}{c}\text { Group A } \\
(\mathrm{n}=30)\end{array}$ & $\begin{array}{c}\text { Group B } \\
(\mathrm{n}=30)\end{array}$ & \\
\hline ASA I & $19(63.3)$ & $18(60.0)$ & \multirow{2}{*}{$0.790^{\mathrm{ns}}$} \\
\hline ASA II & $11(36.7)$ & $12(40.0)$ & \\
\hline
\end{tabular}

Table 2 showed the American Society of Anesthesiologist (ASA) physical status. There was no significant difference between the groups $(\mathrm{p}=0.790)$. Comparison was done by Chi-Square $\left(\chi^{2}\right)$ test. All 60 enrolled patients were randomized to groups, 30 patients of each. All patients were with ASA physical status I and II. Group A, 19(63.3) were ASA I and 11(36.7) were ASA II. Group B, 18(60.0) were ASA I and 12(40.0) were ASA

II.

Table- 3: Distribution of patients according to indications of surgery $(\mathrm{N}=60)$

\begin{tabular}{|l|c|c|}
\hline Indications of surgery & $\begin{array}{c}\text { Frequency } \\
(\mathbf{n})\end{array}$ & $\begin{array}{c}\text { Percentage } \\
(\mathbf{\%})\end{array}$ \\
\hline Supracondyalr fracture & 21 & 35.0 \\
\hline Fracture radius ulna & 27 & 45.0 \\
\hline Olecranon fracture & 8 & 13.3 \\
\hline Fracture neck of humerus & 4 & 6.7 \\
\hline
\end{tabular}




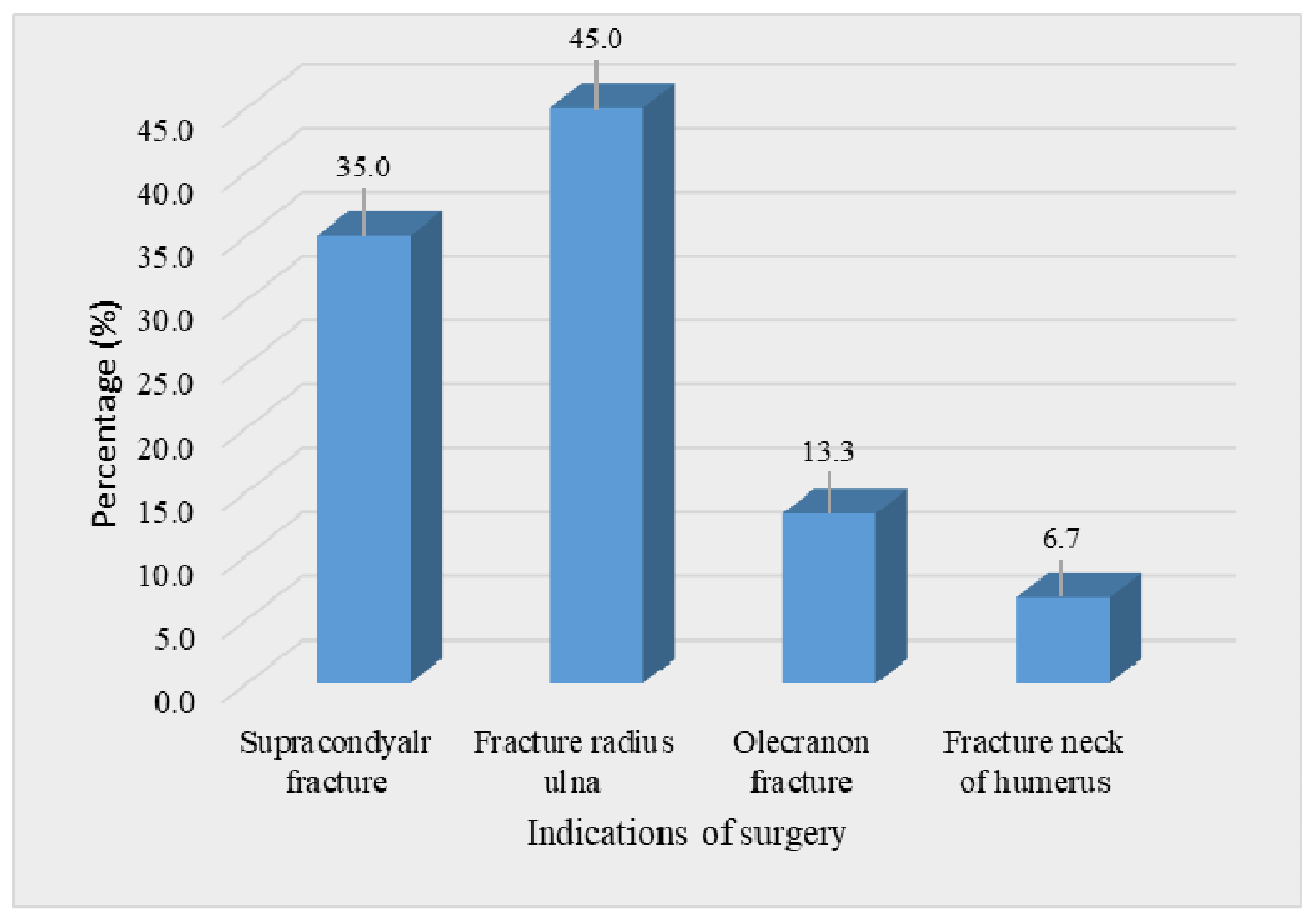

Figure II: Participants Types of Surgery Procedures Distribution (N=60)

Figure II: Bar diagram showed the distribution of patients according to indications of surgery. Indication for surgery was supracondylar fracture $(35.0 \%)$, fracture radius-ulna $(45.0 \%)$, olecranon fracture $(13.3 \%)$, and fracture neck of humerus $(6.7 \%)$.

Table- 4: Distribution of patients according to time of onset of sensory block $(\mathrm{N}=60)$

\begin{tabular}{|l|c|c|c|}
\hline \multirow{2}{*}{ Time (min) } & \multicolumn{2}{|c|}{ Number of Patient } & \multirow{2}{*}{ p-Value } \\
\cline { 2 - 3 } & Group A (n=30) & Group B (n=30) & \\
\hline$\leq 5$ & $2(6.7)$ & $0(0.0)$ & $0.150^{\mathrm{ns}}$ \\
\hline $6-10$ & $23(76.6)$ & $19(63.3)$ & $0.259^{\mathrm{ns}}$ \\
\hline$>10$ & $5(16.7)$ & $11(36.7)$ & $0.079^{\mathrm{ns}}$ \\
\hline Mean \pm SD & $8.17 \pm 1.4 \mathrm{~min}$ & $9.12 \pm 1.68 \mathrm{~min}$ & $0.825^{\mathrm{ns}}$ \\
\hline
\end{tabular}

Table 4 showed time to onset of sensory block. Onset of sensory block was faster in Group A $(8.17 \pm 1.4 \mathrm{~min})$ than Group B $(9.12 \pm 1.68 \mathrm{~min})$. On comparison of the required time to achievement of sensory block between groups, required time was 6-10 minute in $23(76.6 \%)$ patients of group-A versus $19(63.3 \%)$ in Group-B patients. The result was nonsignificant ( $\mathrm{p}$ value $>0.05$ ). 


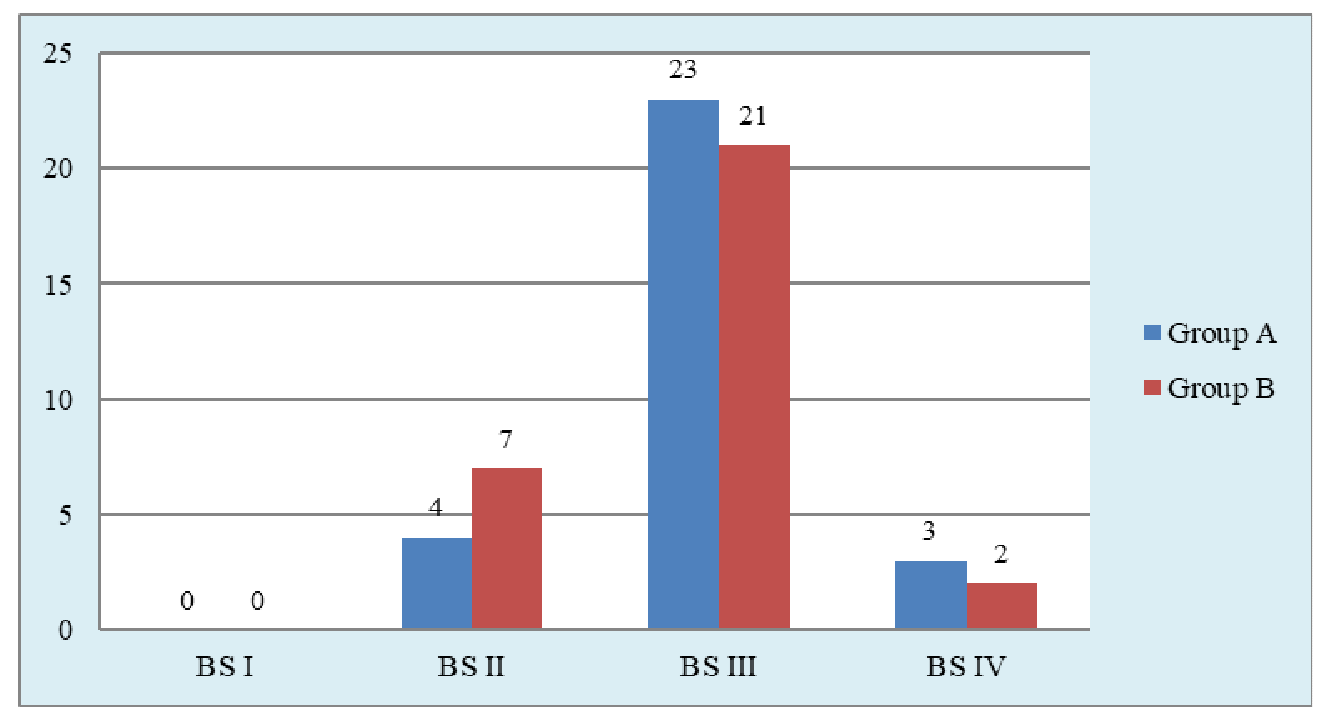

Figure- III: Assessment of Bromage scale and time to onset of motor block $(\mathrm{N}=60)$

Figure III showed the Bromage scale between groups at $10^{\text {th }}$ minute time. Onset of motor block was $12.26 \pm 3.96$ min in Group A patients and $11.58 \pm 3.68 \mathrm{~min}$ in Group B patients. The difference was statistically non- significant. Time taken to achieve Bromage 3 following anaesthesia was considered as onset of motor block. An average Bromage score of 4 was achieved for the motor block in both groups $(\mathrm{p}=0.968)$

Table 5: Distribution of patients according to time of onset of motor block $(\mathrm{N}=60)$

\begin{tabular}{|c|c|c|c|}
\hline \multirow[t]{2}{*}{ Time (min) } & \multicolumn{2}{|c|}{ Number of Patient } & \multirow[t]{2}{*}{ p- Value } \\
\hline & Group A $(n=30)$ & Group B $(n=30)$ & \\
\hline$\leq 10$ & $4(13.3 \%)$ & $7(23.3 \%)$ & $0.317^{\mathrm{ns}}$ \\
\hline $6-10$ & $23(76.7 \%)$ & $21(70.0 \%)$ & $0.559^{\mathrm{ns}}$ \\
\hline$>10$ & $3(10.0 \%)$ & $2(6.7 \%)$ & $0.640^{\mathrm{ns}}$ \\
\hline Mean \pm S.D. & $12.26 \pm 3.96 \mathrm{~min}$ & $11.58 \pm 3.68 \mathrm{~min}$ & $0.968^{\mathrm{ns}}$ \\
\hline
\end{tabular}

Table 5 showed time to onset of motor block. The mean onset time of motor block in group A was $12.26 \pm 3.96 \mathrm{~min}$, and $11.58 \pm 3.68 \mathrm{~min}$ in group B. By evaluating these times, we understood that the required time for initiating motor block in group A was longer than groups $\mathrm{B}$, but the difference between group was statistically non-significant $(\mathrm{p}$ Value $=0.968)$

Table 6: Distribution of patients according to heart rate per minute $(\mathrm{N}=60)$

\begin{tabular}{|c|c|c|c|}
\hline Time & $\begin{array}{c}\text { Group A }(\mathbf{n}=30) \\
\text { Mean } \pm \text { SD }\end{array}$ & $\begin{array}{c}\text { Group B }(\mathbf{n}=30) \\
\text { Mean } \pm \text { SD }\end{array}$ & p-Value \\
\hline Pre-operative & $88.1 \pm 4.7$ & $80.3 \pm 5.1$ & $0.036^{\mathrm{s}}$ \\
\hline $5 \mathrm{~min}$ & $85.1 \pm 5.4$ & $83.2 \pm 6.2$ & $0.080^{\mathrm{ns}}$ \\
\hline $10 \mathrm{~min}$ & $84.3 \pm 5.2$ & $83.2 \pm 4.3$ & $0.209^{\mathrm{ns}}$ \\
\hline $15 \mathrm{~min}$ & $84.6 \pm 5.3$ & $82.7 \pm 6.4$ & $0.081^{\mathrm{ns}}$ \\
\hline
\end{tabular}




\begin{tabular}{|c|l|l|l|}
\hline $20 \mathrm{~min}$ & $84.7 \pm 5.4$ & $82.8 \pm 6.3$ & $0.093^{\text {ns }}$ \\
\hline $30 \mathrm{~min}$ & $83.2 \pm 7.6$ & $82.2 \pm 5.1$ & $0.399^{\text {ns }}$ \\
\hline $45 \mathrm{~min}$ & $85.4 \pm 4.2$ & $86.3 \pm 7.2$ & $0.405^{\text {ns }}$ \\
\hline $60 \mathrm{~min}$ & $86.3 \pm 5.6$ & $88.2 \pm 5.7$ & $0.091^{\text {ns }}$ \\
\hline $90 \mathrm{~min}$ & $86.5 \pm 5.8$ & $88.1 \pm 5.1$ & $0.111^{\text {ns }}$ \\
\hline $120 \mathrm{~min}$ & $85.4 \pm 4.3$ & $86.3 \pm 7.1$ & $0.421^{\text {ns }}$ \\
\hline $150 \mathrm{~min}$ & $86.3 \pm 5.7$ & $88.2 \pm 5.6$ & $0.195^{\text {ns }}$ \\
\hline $180 \mathrm{~min}$ & $86.5 \pm 5.9$ & $88.1 \pm 5.7$ & $0.245^{\text {ns }}$ \\
\hline
\end{tabular}

In the Group A initial heart rate was 88 beats/ minute. In the Group B initial pulse rate was 80 beats/ minute. Clinically and statistically there is no decrease in Pulse Rate in two groups.

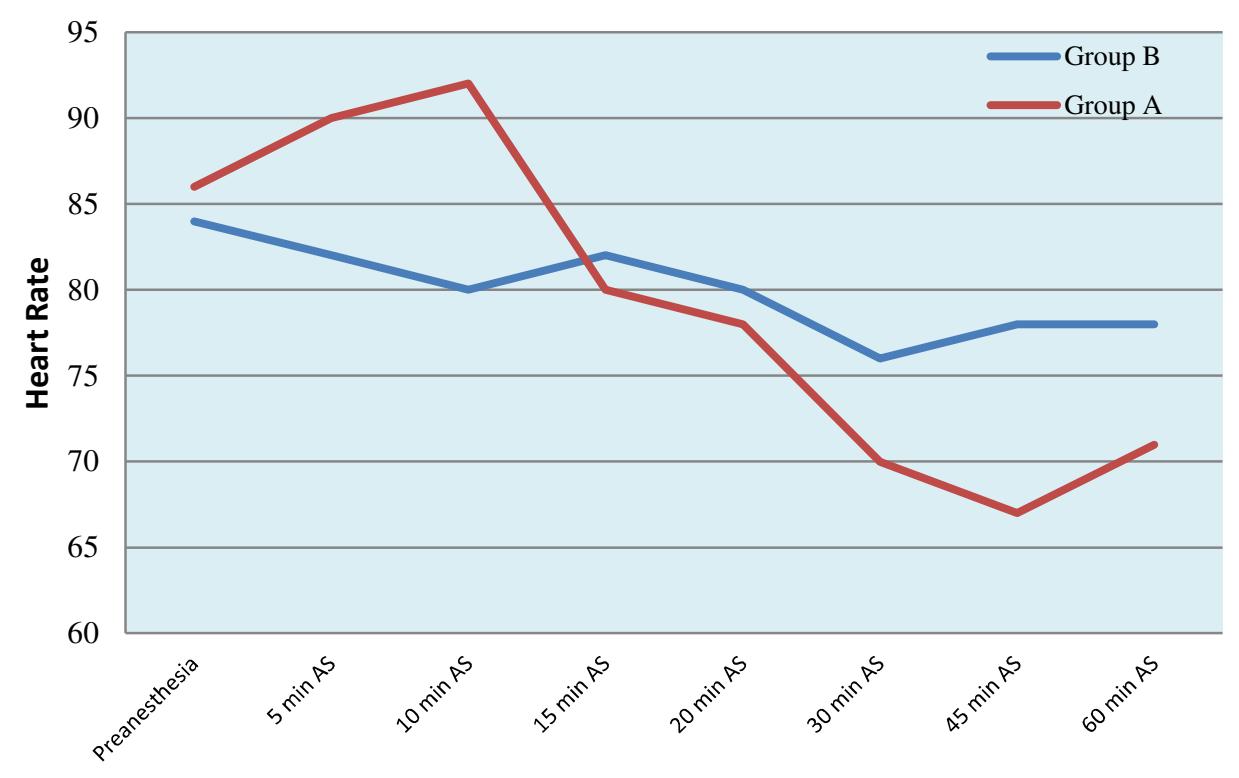

Figure- IV: Trends of heart rate (HR) in the studied group ( $\mathrm{n}=60)$

Figure IV showed the heart rate in the studied group. Regarding the heart rate, no significant difference was detected between the groups at the time of preanesthesia and at the $5 \mathrm{~min}$ after anaesthesia. Compared with group B patients, group A patient shows slight but statistically significant increased heart rate at the $10 \mathrm{~min}(80,92 \mathrm{beat} / \mathrm{min}$ respectively) after supraclavicular brachial plexus block.
Following that heart rate decreased between B group and A group @ 82 and 80 beat/min at $15^{\text {th }} \mathrm{min}, 80$ and $78 \mathrm{beat} / \mathrm{min}$ at $20^{\text {th }} \mathrm{min}, 76$ and $70 \mathrm{beat} / \mathrm{min}$ at $30^{\text {th }} \mathrm{min}, 78$ and 67 beat $/ \mathrm{min}$ at $45^{\text {th }}$ min respectively, but more bradycardia was observed in Group-A. After 45-minute heart rate difference was significant between groups. So that, we found heart rate almost stabilized in B group. 
Table 7: Distribution of patients according to systolic blood pressure between groups with respect to time $(\mathrm{N}=60)$

\begin{tabular}{|l|c|c|c|}
\hline \multicolumn{1}{|c|}{ Systolic BP (mmHg) } & $\begin{array}{c}\text { Group A }(\mathbf{n = 3 0}) \\
\text { Mean } \pm \text { SD }\end{array}$ & $\begin{array}{c}\text { Group B }(\mathbf{n = 3 0}) \\
\text { Mean } \pm \text { SD }\end{array}$ & p- Value \\
\hline Preanesthesia & $89.6 \pm 6.3$ & $84.3 \pm 5.0$ & $0.261^{\text {ns }}$ \\
\hline Range (min-max) & $80-100$ & $80-95$ & \\
\hline 5 min AS & $92.5 \pm 6.8$ & $88.4 \pm 9.2$ & $0.421^{\text {ns }}$ \\
\hline Range (min-max) & $80-105$ & $62-95$ & \\
\hline 10 min AS & $95.3 \pm 7.1$ & $85.5 \pm 5.1$ & $0.031^{\text {s }}$ \\
\hline Range (min-max) & $86-110$ & $80-110$ & \\
\hline 15 min AS & $95.6 \pm 11.2$ & $84.3 \pm 4.8$ & $0.013^{\text {s }}$ \\
\hline Range (min-max) & $85-110$ & $80-95$ & \\
\hline 20 min AS & $97.9 \pm 4.7$ & $88.3 \pm 5.0$ & $0.041^{\text {s }}$ \\
\hline Range (min-max) & $45-105$ & $80-95$ & \\
\hline 30 min AS & $94.6 \pm 15.6$ & $90.8 \pm 5.0$ & $0.082^{\text {ns }}$ \\
\hline Range (min-max) & $90-105$ & $80-95$ & \\
\hline 45 min AS & $93.6 \pm 11.6$ & $89.3 \pm 8.2$ & $0.156^{\text {ns }}$ \\
\hline Range (min-max) & $80-105$ & $70-95$ & \\
\hline 60 min AS & $59.6 \pm 6.0$ & $61.2 \pm 9.4$ & $0.467^{\text {ns }}$ \\
\hline Range (min-max) & $45-110$ & $80-95$ & \\
\hline 90 min AS & $65.2 \pm 5.2$ & $64.3 \pm 8.9$ & $0.634^{\text {ns }}$ \\
\hline Range (min-max) & $50-112$ & $55-93$ & \\
\hline 120 min AS & $66.1 \pm 6.0$ & $65.2 \pm 10.4$ & $0.683^{\text {ns }}$ \\
\hline Range (min-max) & $55-110$ & $60-95$ & \\
\hline 150 min AS & $68.1 \pm 6.0$ & $66.2 \pm 8.5$ & $0.321^{\text {ns }}$ \\
\hline Range (min-max) & $60-110$ & $60-80$ & \\
\hline 180 min AS & $64.6 \pm 7.0$ & $63.2 \pm 9.4$ & $0.516^{\text {ns }}$ \\
\hline Range (min-max) & $55-110$ & $50-95$ & \\
\hline
\end{tabular}

Table 7 showed systolic blood pressure during follow up it was observed that at preanesthesia, mean systolic BP was found $89.6 \pm 6.3 \mathrm{mmHg}$ in group $\mathrm{A}$ and $84.3 \pm 5.0$ $\mathrm{mmHg}$ in group B. At induction, mean systolic blood pressure was $92.5 \pm 6.8 \mathrm{mmHg}$ and $81.4 \pm 9.2 \mathrm{mmHg}$ in group $\mathrm{A}$ and group $\mathrm{B}$ respectively. At incision, mean systolic blood pressure was $95.3 \pm 7.1 \mathrm{mmHg}$ in group $\mathrm{A}$ and $85.5 \pm 5.1 \mathrm{mmHg}$ in group B. At 15 minute after, mean systolic blood pressure was $95.6 \pm 11.2 \mathrm{mmHg}$ and $84.3 \pm 4.8 \mathrm{mmHg}$ in group A and group B respectively. At 30 minute after, mean systolic BP was $97.9 \pm 4.7$ $\mathrm{mmHg}$ in group $\mathrm{A}$ and $84.3 \pm 5.0 \mathrm{mmHg}$ in group B. At 45 minute after, mean systolic blood pressure was $94.6 \pm 15.6 \mathrm{mmHg}$ and $84.3 \pm 5.0 \mathrm{mmHg}$ in group $\mathrm{A}$ and group $\mathrm{B}$ respectively. At 60 minutes after, mean systolic blood pressure was $59.6 \pm 6.0 \mathrm{mmHg}$ in group $\mathrm{A}$ and $61.2 \pm 9.4 \mathrm{mmHg}$ in group $\mathrm{B}$. At 10, 15 and 20-minute difference was statistically significant $(\mathrm{p}<0.05)$ between two groups. 
Table 8: Distribution of patients according to diastolic blood pressure (DBP) between groups with respect to time $(\mathrm{N}=60)$

\begin{tabular}{|l|c|c|c|}
\hline $\begin{array}{l}\text { Diastolic BP } \\
(\mathbf{m m H g})\end{array}$ & $\begin{array}{c}\text { Group A }(\mathbf{n}=\mathbf{3 0}) \\
\text { Mean } \pm \text { SD }\end{array}$ & $\begin{array}{c}\text { Group B }(\mathbf{n}=\mathbf{3 0}) \\
\text { Mean } \pm \text { SD }\end{array}$ & p- Value \\
\hline Preanesthesia & $59.6 \pm 6.0$ & $61.2 \pm 9.4$ & $0.348^{\mathrm{ns}}$ \\
\hline Range (min-max) & $50-70$ & $45-80$ & \\
\hline 5 min AS & $63.9 \pm 5.2$ & $61.2 \pm 9.6$ & $0.213^{\mathrm{ns}}$ \\
\hline Range (min-max) & $55-70$ & $45-80$ & \\
\hline 10 min AS & $65.4 \pm 5.6$ & $62.5 \pm 9.5$ & $0.186^{\mathrm{ns}}$ \\
\hline Range (min-max) & $55-75$ & $45-80$ & \\
\hline 15 min AS & $67.6 \pm 7.4$ & $61.5 \pm 9.7$ & $0.013^{\mathrm{s}}$ \\
\hline Range (min-max) & $50-75$ & $45-80$ & \\
\hline 20 min AS & $65.5 \pm 7.1$ & $61.9 \pm 9.7$ & $0.096^{\mathrm{ns}}$ \\
\hline Range (min-max) & $50-75$ & $45-80$ & \\
\hline 30 min AS & $66.0 \pm 6.8$ & $61.2 \pm 9.4$ & $0.039^{\mathrm{s}}$ \\
\hline Range (min-max) & $50-75$ & $45-80$ & \\
\hline 45 min AS & $65.2 \pm 5.6$ & $60.5 \pm 9.5$ & $0.001^{\mathrm{s}}$ \\
\hline Range (min-max) & $55-75$ & $45-80$ & \\
\hline 60 min AS & $59.5 \pm 5.0$ & $60.2 \pm 7.4$ & $0.432^{\mathrm{ns}}$ \\
\hline Range (min-max) & $50-70$ & $45-80$ & \\
\hline 90 min AS & $63.4 \pm 6.2$ & $64.2 \pm 7.3$ & $0.649^{\mathrm{ns}}$ \\
\hline Range (min-max) & $55-75$ & $55-80$ & \\
\hline 120 min AS & $65.2 \pm 6.9$ & $64.3 \pm 6.1$ & $0.594^{\mathrm{ns}}$ \\
\hline Range (min-max) & $60-75$ & $60-80$ & \\
\hline 150 min AS & $66.8 \pm 6.3$ & $65.7 \pm 6.1$ & $0.494^{\mathrm{ns}}$ \\
\hline Range (min-max) & $60-75$ & $65-80$ & \\
\hline 180 min AS & $63.3 \pm 5.5$ & $55-75$ & $0.389^{\mathrm{ns}}$ \\
\hline Range (min-max) & & & \\
\hline
\end{tabular}

Regarding diastolic blood pressure during follow up, after 15 minute, 30 minutes, and 45 minutes mean diastolic blood pressure was statistically significant $(\mathrm{p}<0.05)$ between two groups but other follow up were not significant $(\mathrm{p}>0.05)$ between two groups.

Table 9: Distribution of patients according to mean arterial pressure (MAP) between groups with respect to time $(\mathrm{N}=60)$

\begin{tabular}{|l|c|c|c|}
\hline \multirow{2}{*}{$\begin{array}{l}\text { Time point after } \\
\text { block }\end{array}$} & \multicolumn{2}{|c|}{$\begin{array}{c}\text { Mean arterial pressure -MAP } \\
(\mathbf{m m H g})\end{array}$} & \multirow{2}{*}{ p- Value } \\
\cline { 2 - 3 } & $\begin{array}{c}\text { Group A } \\
(\mathbf{n}=\mathbf{3 0}) \\
\text { Mean } \pm \text { SD }\end{array}$ & $\begin{array}{c}\text { Group B } \\
(\mathbf{n}=\mathbf{3 0}) \\
\text { Mean } \pm \text { SD }\end{array}$ & \\
\hline Pre-anaesthesia & $69.60 \pm 11.6$ & $68.93 \pm 9.1$ & $0.883^{\text {ns }}$ \\
\hline 5 min AS & $70.45 \pm 8.2$ & $67.90 \pm 9.5$ & $0.086^{\text {ns }}$ \\
\hline 10 min AS & $75.40 \pm 7.9$ & $70.25 \pm 10.2$ & $0.0001^{\text {s }}$ \\
\hline 15 min AS & $76.92 \pm 8.1$ & $69.18 \pm 9.5$ & $0.0001^{\text {s }}$ \\
\hline
\end{tabular}




\begin{tabular}{|l|c|c|c|}
\hline $20 \min \mathrm{AS}$ & $76.31 \pm 8.6$ & $68.73 \pm 9.1$ & $0.0001^{\mathrm{s}}$ \\
\hline $30 \mathrm{~min} \mathrm{AS}$ & $71.57 \pm 10.2$ & $69.18 \pm 7.5$ & $0.067^{\text {ns }}$ \\
\hline $45 \mathrm{~min} A S$ & $71.05 \pm 9.3$ & $68.46 \pm 11.4$ & $0.435^{\text {ns }}$ \\
\hline $60 \mathrm{~min} A S$ & $59.55 \pm 6.8$ & $60.52 \pm 7.1$ & $1.082^{\text {ns }}$ \\
\hline $90 \mathrm{~min} A S$ & $63.45 \pm 7.1$ & $62.71 \pm 9.12$ & $0.723^{\text {ns }}$ \\
\hline $120 \mathrm{~min} A S$ & $64.71 \pm 7.3$ & $61.8 \pm 8.2$ & $0.723^{\text {ns }}$ \\
\hline $150 \min \mathrm{AS}$ & $65.5 \pm 7.3$ & $63.7 \pm 8.7$ & $0.389^{\text {ns }}$ \\
\hline $180 \mathrm{~min} A S$ & $64.46 \pm 7.6$ & $62.4 \pm 7.12$ & $0.283^{\text {ns }}$ \\
\hline
\end{tabular}

There was no significant difference between the groups as regards Preanaesthetic period MAP $(p=0.883)$, but after anesthesia significant decrease in MAP was seen in all groups compared with basal MAP, the least decrease occurring in the group $\mathrm{A}$ and the highest fall in the group B. At the $15^{\text {th }}$ minute MAP was 76.92 and $69.18 \mathrm{~mm}$ of $\mathrm{Hg}$ in group $A$ and group $B$ respectively showing significant difference $(\mathrm{p}=0.0001)$, After 45 minute, mean blood pressure was $71.05 \pm 6.8$ $\mathrm{mmHg}$ in group A and $68.46 \pm 9.4 \mathrm{mmHg}$ in group B. Which statistically significant $(p<0.05)$ between two groups but follow up after 60, 90, 120, 150 and 180 minutes mean BP stabilized to similar in both group, which was statistically not significant $(p>0.05)$ between two groups.

Table 10: Distribution of patients according to mean duration of motor and sensory block between two groups $(\mathrm{N}=60)$

\begin{tabular}{|l|c|c|c|}
\hline \multirow{2}{*}{ Variable } & \multicolumn{2}{|c|}{$\begin{array}{c}\text { Duration of motor and sensory block } \\
\text { (min) }\end{array}$} & \multirow{2}{*}{$\begin{array}{c}\text { p- } \\
\text { Value }\end{array}$} \\
\cline { 2 - 3 } & $\begin{array}{c}\text { Group A (n=30) } \\
\text { Mean } \pm \text { SD }\end{array}$ & $\begin{array}{c}\text { Group B (n=30) } \\
\text { Mean } \pm \text { SD }\end{array}$ & \\
\hline Duration of sensory block (min) & $457.13 \pm 36.12$ & $428.15 \pm 31.42$ & $0.001^{\mathrm{s}}$ \\
\hline Duration of motor block (min) & $408.68 \pm 26.96$ & $380.26 \pm 24.11$ & $0.001^{\mathrm{s}}$ \\
\hline
\end{tabular}

The duration of sensory blockade, defined as the time between onset of sensory block and return of dull pain but $\mathrm{VAS}<3$. The duration of motor block was assessed every 10 minutes till the ability of the patient to first move the fingers. Sensory and motor block lasted longer in the group-A patients as compared to the Group-B, the difference was statistically significant $(\mathrm{p}<0.05)$. Present study shows that duration of motor block was $408.68 \pm 26.96 \mathrm{~min}$ and $380.26 \pm 24.11 \mathrm{~min}$ in group A and Group B respectively. Sensory block was $457.13 \pm 36.12$ min and $428.15 \pm 31.42 \mathrm{~min}$ in group A and Group B respectively, which is statistically significant difference between two groups $(\mathrm{p}<0.05)$. 


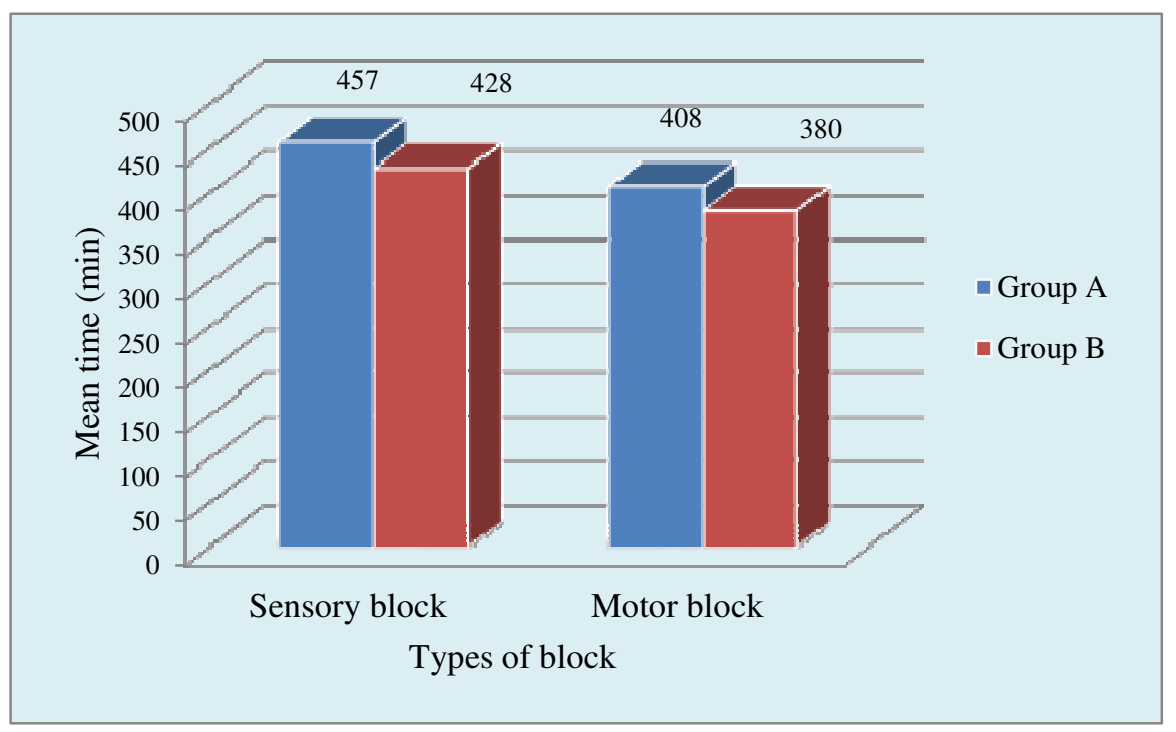

Figure- V: Mean duration ( $\mathrm{min})$ of motor and sensory block $(\mathrm{N}=60)$

\section{DISCUSSION}

In present study showed no significant difference between groups in respect of demographic variables and ASA status $(\mathrm{p}>0.05)$. In accordance Sayed et al. ${ }^{8}$ reported non-significant differences between study groups as regards to age, sex, ASA and body weight variations. In this study onset of sensory and motor block was faster in Group A than Group B., but the difference between group was statistically non-significant. Nath et al. ${ }^{9}$ found that the use of magnesium caused a delay in onset of sensory and motor block, but it was statistically insignificant. Similar results were observed by Khezri et al. ${ }^{\mathbf{1 0}}$ and Malleeswaran et al. ${ }^{11}$ The mean onset of sensory block in case Group M was $15.5 \pm 2.16$ and the onset block in control Group $\mathrm{P}$ was $12.73 \pm 1.18(\mathrm{p}<0.49)$. The mean onset of motor block in case Group $M$ was $23.5 \pm 1.1$ and the onset block in control Group $\mathrm{P}$ was $41 \pm 3$ $(p<0.53) .{ }^{12}$ In our study, haemodynamics was not statistically significant $(\mathrm{p}>0.05)$ between two groups. Hamed et al. ${ }^{13}$ illustrated that there is no statistically significance difference with $\mathrm{P}>0.05$ between study groups as regards the intraoperative HR follow-up in the 1st hr., which indicated all groups of drugs had same effect on intraoperative HR. In present study showed the duration of sensory and motor block was significantly increased in Group A compare to Group B $(\mathrm{p}<0.05)$. Study by Rao et $\mathrm{al}^{\mathbf{1 2}}$ demonstrated that addition of magnesium sulfate to $0.5 \%$ bupivacaine increased the duration of motor and sensory supraclavicular brachial block in the upper extremities during surgeries when compared to the use of $0.5 \%$ bupivacaine alone. In their study 30 patients having received $0.5 \%$ bupivacaine plus magnesium and the other 30 patients having received $0.5 \%$ bupivacaine plus normal saline. The mean sensory block duration in the case

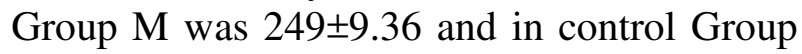
$\mathrm{P}$ was $160 \pm 5.62(\mathrm{p}<0.39)$. The mean motor block duration in the case Group $M$ was $232 \pm 9.64$ and in control Group $\mathrm{P}$ was $147 \pm 26.52$ (both $\mathrm{p}<0.32$ ). Through statistically not significant but definitely in clinically significant. Fentanyl used with bupivacaine in our study prolonged the duration of sensory and motor blockade, probably by directly binding with opioid binding sites on the dorsal nerve roots aided with these axonal transport or by diffusing into surrounding tissues and subsequently into the epidural and subarachnoid spaces, it may also have been 
central opioid receptor mediated after systemic absorption of fentanyl. Another study uses of opioids for brachial plexus block have reported to prolong the analgesic duration with or without the use of local anaesthetics. ${ }^{6}$ Madusudhan et al (2011) demonstrated a significant increase in the duration of sensory, motor blockade on addition of fentanyl to ropivacaine $0.75 \%$ for brachial plexus blocks compared to ropivacaine used alone, which were similar to our study results. In our study, the addition of fentanyl to local anesthetics for brachial plexus block (Group-A) improved the success rate of nerve block.14 Rajkhowa $\mathrm{T}$ et al (2016) $)^{15}$ showed that, Supraclavicular brachial plexus block was performed in the group $\mathrm{R}$ using $0.5 \%$ ropivacaine and in group $\mathrm{RF}$ received $0.5 \%$ ropivacaine plus 50 micrograms fentanyl. Compared to group $\mathrm{R}$, group $\mathrm{RF}$ showed a significant greater duration of sensory and motor blockade $(P=0.0001)$. The addition of fentanyl to ropivacaine significantly prolonged the duration of analgesia compared to ropivacaine used alone for supraclavicular brachial plexus blocks in patients undergoing forearm surgeries. ${ }^{15}$ The analgesic/antinociceptive effect of opiates is primarily mediated at the central and/or spinal cord level. Some studies have reported the existence of peripheral functional opioid receptors in animals, but their existence in human peripheral tissue is still doubtful. In present study showed no significant difference of mean time for requirement of rescue analgesic between Group A and Group B ( $=0.127)$. No significant difference of total number of rescue analgesics between Group A and Group B $(\mathrm{p}=0.640)$. In accordance Hamed et al. ${ }^{13}$ reported postoperative VAS values at 24 hours were significantly lower in group $M$ than group N. Another study ${ }^{16}$ reported adding magnesium sulfate to supraclavicular brachial plexus block may increase the sensory and motor block duration and time to first analgesic use, and decrease total analgesic needs, with no side effects. In their study one hundred patients undergone supraclavicular brachial plexus block were divided into two equal groups). In group $\mathrm{RM}(\mathrm{n}=50), 30 \mathrm{ml}$ $0.5 \%$ ropivacaine plus $150 \mathrm{mg}$ magnesium sulfate and in group $\mathrm{RN}(\mathrm{n}=50), 30 \mathrm{ml} 0.5 \%$ ropivacaine plus $1 \mathrm{ml}$ normal saline were administered in supraclavicular block. The mean time from block placement to first request for pain medication, that is, the duration of analgesia was $461.71 \mathrm{~min}$ in the Magnesium sulfate group but $379.79 \mathrm{~min}$ in the normal saline group. This difference (about $81.92 \mathrm{~min})$ was statistically significant $(\mathrm{P}=$ 0.02). Group RM required less amount of diclofenac sodium injection as rescue analgesics than patients in group RN (saline group) in first $24 \mathrm{~h}$ of postoperative period..$^{16}$ From this study it is found that magnesium sulphate as well as fentanyl as an adjuvant to bupivacaine prolongs the duration of sensory and motor block in supraclavicular brachial plexus block; but fentanyl is better than magnesium sulphate in this aspect.

\section{LIMITATIONS OF THE STUDY}

The present study was conducted in a very short period of time. All the patients admitted to Bangladesh Medical College and Hospital, Dhaka was taken for the study. So this will not reflect the overall picture of the country.

\section{CONCLUSIONS} RECOMMENDATIONS

AND

Magnesium sulphate chloride, as well as fentanyl as an adjuvant to bupivacaine, prolongs supraclavicular brachial plexus block. Fentanyl as magnesium sulphate chloride should be used as an adjuvant. Further studies could be undertaken by including a large number of patients in multiple tertiary hospitals.

\section{REFERENCES}

1. Neal JM, Gerancher JC, Hebl JR, Ilfeld BM, McCartney CJ, Franco CD, Hogan QH. Upper extremity regional anesthesia: essentials of our current 
understanding, 2008. Regional Anesthesia \& Pain Medicine. 2009 Feb 1;34(2):134-70.

2. Kothari D. Supraclavicular brachial plexus block: A new approach. Indian journal of anaesthesia. 2003 Jul 1;47(4):287.

3. Kusre S, McEwen A, Matthew G. Ultrasound-Guided Supraclavicular Brachial Plexus Block. ATOTW, 2018; 1-8.

4. Yang CM, Kwon HU, Cho CK. A comparison of infraclavicular and supraclavicular approaches to the brachial plexus using neurostimulation. Korean J Anesthesiol.2010; 58(3): 260266.

5. Buttner J. Axillary and mid humeral approach for Brachial Plexus Block. Curr Opin Anaesthesiol, 1998; 11: 499502.

6. Farooq N, Singh RB, Sarkar A, Rasheed $M$ and Choubey S. To Evaluate the Efficacy of Fentanyl and Dexmedetomidine as Adjuvant to Ropivacaine in Brachial Plexus Block: A Double-blind, Prospective, Randomized Study. Anesth Essays Res. 2017; 11(3): 730-739.

7. Mukherjee K, Das A, Basunia S, Dutta S. Evaluation of Magnesium as an adjuvant in Ropivacaine-induced supraclavicular brachial plexus block: A prospective, double-blinded randomized controlled study. J Res Pharm Pract. 2014; 3(4): 123-129.

8. Sayed MB, Mostafa Abd El-Hameed S, Mohammed Yousef Ahmed E. comparative study between dexamethasone and fentanyl as an adjuvant to bupivacaine in ultrasound guided supraclavicular brachial plexus block in upper limb surgeries. Al-Azhar Medical Journal. 2019 Oct 1;48(4):50112.
9. Nath MP, Garg R, Talukdar T, Choudhary D, Chakrabarty A. To evaluate the efficacy of intrathecal magnesium sulphate for hysterectomy under subarachnoid block with bupivacaine and fentanyl: A prospective randomized double blind clinical trial. Saudi journal of anaesthesia. 2012 Jul;6(3):254.

10. Khezri MB, Yaghobi S, Hajikhani M, Asefzadeh S. Comparison of postoperative analgesic effect of intrathecal magnesium and fentanyl added to bupivacaine in patients undergoing lower limb orthopedic surgery. Acta Anaesthesiologica Taiwanica. 2012 Mar 1;50(1):19-24.

11. Malleeswaran S, Panda N, Mathew P, Bagga R. A randomised study of magnesium sulphate as an adjuvant to intrathecal bupivacaine in patients with mild preeclampsia undergoing caesarean section. International journal of obstetric anesthesia. 2010 Apr 1;19(2):161-6.

12. Ramos-Matos C and Lopez-Ojeda W. Fentanyl. National Library of Medicine, National Institutes of Health. Downloaded from: https://www.ncbi.nlm.nih.gov/books/. Retrieved on January 2018.

13. Hamed MA, Ghaber S, Reda A. Dexmedetomidine and Fentanyl as an Adjunct to Bupivacaine $0.5 \%$ in Supraclavicular Nerve Block: A Randomized Controlled Study. Anesth Essays Res. 2018;12(2):475-479. doi:10.4103/aerate

14. Madhusudhana R, Kumar K, Kumar R, Potli S, Karthik D, Kapil M. Supraclavicular brachial plexus block with $0.75 \%$ ropivacaine and with additives tramadol, fentanyl-a comparative pilot study. Int J Biol Med Res. 2011;2(4):1061-3.

15. Rajkhowa T, Das N, Parua S, Kundu R. Fentanyl as an adjuvant for brachial 
plexus block: A randomized comparative study. Int J Clin Trials. 2016 Apr;3(2):64-7.

16. Rao L, Jeyalakshmi V, Nagaraju M, Anitha S. The effect of magnesium sulfate as an adjuvant to $0.5 \%$ bupivacaine on motor and sensory supraclavicular brachial plexus blockade. International Journal of Basic \& Clinical Pharmacology | March-April 2015; 4(2): 317-20. 